Journal of Social and Development Sciences

Vol. 2, No. 3, pp. 121-130, Sep 2011 (ISSN 2221-1152)

\title{
Leadership Effectiveness, Truth Commissions and Democratization in Africa
}

\author{
${ }^{*}$ Chux Gervase Iwu ${ }^{1}$, Gbadamosi T. Adeola ${ }^{2}$ \\ ${ }^{1}$ Faculty of Business, Cape Peninsula University of Technology, Cape Town, South Africa \\ ${ }^{2}$ Institute of African Studies, University of Ibadan, Nigeria \\ *iwuc@cput.ac.za
}

\begin{abstract}
This paper explores the significance of transformational and political leadership in strengthening the capacities of truth commissions as effective mechanisms for democratization in transitional polities. First, the paper sets out to trace some of the conflicting goals and political compromises that attend to the establishment of truth commissions in Africa as well as lack of political will on the part of political leadership. The paper then identifies and discusses major problems that confront the institutionalization of truth commissions as veritable instruments of post-conflict transformation and democratic consolidation in the continent. Drawing insights from South Africa, Sierra Leone, and Nigeria, the paper argues that national reconciliation processes in Africa are characterized by a paradigm shift from the primary concern of leadership choices to those of justice, truth-seeking, granting of amnesty and forgiveness. In conclusion, the paper stresses the role of transformative leadership as crucial to enhancing the capacities of truth commissions in consolidating democracy in post-conflict states.
\end{abstract}

Keywords: Transformative Leadership, Democracy, Truth Commission, Post-conflict Transformation

\section{Introduction}

Conflict management strategies in Africa and indeed elsewhere around the world have oscillated from one historical epoch to the other in the last few decades. One recent example of such is the movement from retributive to restorative responses to post-conflict issues within the context of what has become widely known as transitional justice. Retribution on the one hand focuses on open trials and prosecutions of perpetrators to establish individual culpability for past wrongs and to serve as a lodestar for re-establishing the law (Evenson, 2004). Restorative justice, on the other hand, involves truth-telling, apology, reparations for victims, forgiveness and amnesty granting for human rights violators or perpetrators, expressed through the proliferations of truth commissions in most post-conflict states of the world. Whether one likes it or not, the institution of truth commissions will for many years continue to dominate the post-conflict thinking of most states that are recovering from past traumas. Although many observers rarely subscribe to this obvious fact, the reality remains that most of these societies cannot afford to continue to blindly pursue retributive justice at the expense of national rebirth, healing and reconciliation. For this reason, truth commissions are being recommended to states that are recovering from post-war traumas and authoritarianism to support transition to democracy and as a means of facilitating national healing and reconciliation. Not surprising therefore that truth commissions have proliferated in quick succession in countries such as Argentina, Chile, Guatemala, Nicaragua, East Timor, Uganda, Nigeria, South Africa, Sierra Leone, Ghana and Rwanda/Burundi among several others. These commissions vary considerably in their methodological orientation, focus, scope, mandate, duration and composition, depending on the circumstances that warranted their establishment (Fombad, 2009).

It remains a conjecture for pessimists as to whether the institution of truth commissions can adequately cope with the complex nature of conflicts in the near future. Indeed, national reconciliation commissions have prospects for resolving virtually all manner of conflicts and reserve the great potential for contributing innovatively to democratic consolidation globally. Africa is no exception in this thinking. Despite this optimism, the works or reports of these bodies have been met with mounting criticisms especially with regard to their capacity to translate rhetoric into concrete action. While truth commissions have become more or less an accepted framework for post conflict reconciliation in Africa, it is worrisome that not much has been done to put the commissions' work in a proper perspective. This laxity is often blamed on nonavailability, methodological preferences, foreign manipulation, expertise, staff strength, scope and timing. The aim of this paper is to critically discuss the modalities for strengthening truth commissions as facilitator or 
important support to democratic consolidation in transiting countries of Africa. The paper identifies transformative leadership as key for re-inventing national reconciliation commissions for sustaining democratic option in post-conflict societies in the continent. References are made to South Africa, Sierra Leone and Nigeria where these models have been tried, to enrich our understanding of the subject.

Nel, et al. (2008) are of the opinion that leadership is the process whereby one individual influences others to willingly and enthusiastically direct their efforts and abilities towards attaining defined group organizational goals. The source of this influence may be formal (formal authority, power and position) and/or informal (traits, charisma) (Robbins, 2009). Intense global competition heaps enormous burden on the leadership of nations. Some of these challenges are encapsulated in the study of Denton and Vloebergs (2003). These include affirmative action and discrimination, worker empowerment, outsourcing of business functions, downsizing as a result of changing organizational forms and of course globalization. The dynamic global community today is therefore characterized not only by these challenges but also by economic malaise and growing concern for good governance (Jensen \& Luthans, 2006).

Leadership literature has a plethora of theories. These theories serve the benefit of describing the different kinds of leadership styles as well as the conditions and/or situations that warrant these kinds of leadership styles. Robert Blake and Jane Mouton propose a managerial grid based on the styles of 'concern for people' and 'concern for production'. The grid shows the dominating factors in a leaders thinking with regards to getting results (Robbins, 2009). Hersey and Blanchard are known for their situational leadership theory which suggests that a leader should adjust his or her style to suit his followers (Nel et al., 2008). This means that a leader should know the level or state of maturity of his followers before engaging them. These two theories tend to suggest that leaders should pursue the objectives of nation building by involving their followers.

Den Hartog et al (1999) referring to several other studies mention that charismatic or transformational leaders articulate a realistic vision of the future that can be shared, stimulate followers intellectually, and pay attention to the differences among the followers. Tichy and Devanna (1990) highlight the transforming effect these leaders can have on societies as well as on individuals. It is often claimed that by defining the need for change, creating new visions, and mobilizing commitment to these visions, leaders can ultimately transform organizations. In furtherance to this, Jensen and Luthans (2006) counsel 'creating and sustaining a successful transition demands not only vision and financial capital, but also leading others to transform that vision and financial capital into a successful reality. Thus leadership should be about setting aside self-interest for the betterment of followers and organizations (George, 2003; Boyatzis \& McKee, 2005). This admonition resonates well with Den Hartog et al (1999) who argue that the benefits of charismatic/transformational leadership include broadening and elevating the interests of followers, generating awareness and acceptance among the followers of the purposes and mission of the group, and motivating followers to go beyond their self-interests for the good of the larger society. This essentially calls for a different kind of leadership which Liden et al. (2008) call servant leadership.

Nielsen, Yarker, Randall and Munir (2009) claim that several studies reported strong associations between leadership styles and democracy, yet only few studies have examined the mechanisms that may help explain the relationship. Thus, this paper adds to the literature on the impact of transformational leadership on national reconciliation, while also elucidating the benefits of genuine political leadership. Political leadership is essentially the exercise of seeking consent rather than imposing coercion (Nunes, 2010). In a review of John Cartwright's Political Leadership in Africa (Croom Helm \& St Martin, London), Chabal (1984) wrote: 'Leadership and coercion are at the opposite ends in the art of governance... The success of leadership is measured by the achievements, not merely by the absence of coercion'.

Conceptual Analysis: In order to adequately articulate the central themes of this paper, three major concepts shall be briefly discussed. These concepts include; Truth Commissions, Democracy and Transformative Leadership.

Truth Commission: Various scholars have adopted different definitions to describe what is understood by the term truth commission. According to Borer (2005), a truth commission is a body 'created in a postconflict situation to examine past atrocities, issue finding responsibility, and make future oriented 
recommendations designed to foster and consolidate democracy and a human rights culture'. Teitel (2003) describes a truth commission as 'an official body, often created by a national government, to investigate, document, and report upon human rights abuses within a country over a specified period of time'. However, the most cited definition of truth commissions comes from Hayner (1994), who defines them as 'bodies set up to investigate a past history of violations of human rights in a particular country, which can include violations by the military and other government forces or armed opposition groups'. Perhaps, the deductions from these submissions are, first, truth commissions focus on past human rights abuses. Secondly, they are not permanent bodies and lastly, truth commissions are official institutions sanctioned and authorized by the government. From experience, there exists a disconnect between what a truth commission claims to be and what it eventually does. For this reason, many bodies today claim to be truth commissions simply because they have 'truth' attached to their nomenclature or are mandated to investigate human rights violations. In order to clarify these ambiguities, Freeman and Hayner (2006) provide the following general features of truth commissions:

(a) They are temporary bodies, usually in operation from one to two years;

(b) are officially sanctioned, authorized or empowered by the state, and in some cases by the armed opposition as well as in a peace accord;

(c) are non-judicial bodies that enjoy a measure of de jure independence;

(d) are usually created at the point of political transition; either from war to peace or from authoritarian rule to democracy;

(e) they focus on the past;

(f) investigate pattern of abuses and specific violation committed over a period of time;

(g) complete their work and submit a final report that contains conclusions and recommendations; and

(h) focus on violation of human rights and humanitarian norms as well.

Having established the general features of truth commissions for the purpose of this paper, we wish to state that the terms truth commissions and national reconciliation commissions will be used interchangeably in this paper.

Democracy: In political discourse, the word democracy has won wide currency and is perhaps the most important concept that has engaged the attention of professionals from diverse callings for many decades. Politicians, administrators, diplomats, scholars and public commentators freely use the term sometimes to a point of abuse. This is because the public's understanding of the concept remains vague and rarely practical. Democracy is derived from the Greek words, demos and kratos, that is, people and power. Thus, Kapur (1981) defines democracy simply as 'power to the people'. The simplest definition of democracy today is the one offered by Abraham Lincoln (1809-1865), who described it as the government of the people by the people and for the people (Lincoln, 1980, cited in Pitkin, 2004). The foregoing clearly shows that democracy has a primary constituency that hinges on the domain of the people. However, mere consent of the people does not automatically confer a democratic profile on any government. Democracy is better appreciated within the context of the political space that permits the express transmission of the general will (of the people), which Jean J. Rousseau (2008) says guarantees values such as the rule of law, human rights, equality and liberty. Democracy is consolidated when these ideals of democracy have been entrenched in the postconflict polity. After war or repressive authoritarianism, democratic governance is very crucial for mobilizing the people for social cohesion and national reconciliation. This unique virtue makes consolidating democracy central to the resolution of issues in post-war states.

Transformative Leadership: Leadership is somewhat an elusive concept and difficult to define precisely (Smit, Cronje, Brevis, \& Vrba, 2007). However, there is consensus among researchers (Robbins, Judge, Odendaal, \& Roodt, 2009; Nel, Werner, Haasbroek, Poisat, Sono \& Schultz, 2008; van Zyl, 2009) that leadership encompasses directing, coordinating and leading others towards achieving a group or collective goal. It is the ability to influence people, motivate them to serve a common purpose, and to fulfill the function necessary for successful group action (Rosenbloom, 1998). Leadership involves the exercise of influence and not coercion (Nel et al, 2008). Robbins et al (2009) add that this influence may however be formal. Ikenberry (1996) defines leadership as the ability to foster cooperation and commonality of social purpose among individuals or states. The essence of leadership is mobilizing followers for positive action. Yet, the concept 
cannot be devoid or separated from the word followership. Thus, Albert (2003) observes that 'whenever we refer to leadership, mention must also be made of followership'. This is because, according to him, leadership cannot exist in a vacuum and indeed leaders emerge from the rank and file of their followers and are always accountable to them. Leadership then succeeds when room is created for followers to actively participate in decision-making structure of an organization or group. In other words, legitimate political power is a sine qua non for positive change to take place within an organization or in any political setting. Transformative leadership is then the ability of the leader to positively create a change within followership and the environment within which he operates. The transformative character of leadership therefore emits from its ability to elicit consensus among various interests for the general well-being of the group.

\section{Truth Commissions and Leadership Transformation Theory}

The emergence of truth commissions in post-conflict equation of nations that are recovering from past traumas has become a subject of intense academic debate for quite for a long time. Various studies on postconflict settlement and peace-building have shown that the conduct and outcome of national reconciliation commissions are shaped by several salient factors. According to Vora and Vora (2004), many different and complex factors and circumstances contribute to the success or otherwise of a truth commission. Hayner (1994), for instance, identifies such key factors as timing, authority, representation, scope and budget to be important determinants of the effectiveness of a truth commission. Zalaquett (1997) emphasizes the uprightness and integrity of members of the commission as hallmarks of any successful truth commissions.

Regrettably, most authors of post-conflict studies rarely devote enough time to assess the role of leadership in framing truth commissions as we are presently experiencing it all over world. It is on this basis that this paper intends to adopt the theory of transformative leadership to articulate the main ideas of this paper. The theory of transformative leadership was developed by James Burn in 1978 and was originally borrowed from Weberian concept of charismatic leadership. According to Burn (cited in Albert, 2003), transformative leadership aims at transforming followership in order to facilitate collaboration towards achieving common goals. Transformational leadership follows the pattern of advancing maximum cooperation and robust exchanges between the leader and his followers for the desired positive change to take place. Transformation though, warns Nel, et al (2008) is a difficult and long-term process.

The hallmark of transformative leadership is, essentially, to bring about the positive change that is necessary for group attainment of set goals. Transformative actions demand that leaders input certain positive traits or characteristics into their followers, which can have a spill-over effect on the larger society. In other words, leaders teach their followers self-confidence such that followers become more capable of independent, positive and autonomous action (Sashkin \& Rosenbach, 1993).

Experience has shown that truth commissions require the matrix of transformative leadership to succeed. The successes recorded by the South African Truth and Reconciliation Commission were largely attributable to the visionary leadership of Nelson Mandela and Archbishop Desmond Tutu. Leaders have the sole responsibility to incorporate the people they lead into the vision they have for them. Indeed, the roles played by policy makers in achieving favourable outcomes for truth commissions cannot be overemphasized. Lyster (cited in Quinn \& Freeman, 2003) observes that:

'it is the responsibility of these people (leaders) to provide a clear and detailed outline of their vision for the commission, including the theoretical parameters they intend to articulate. In doing so, they ought to bear in mind the expectation created by the vision they create'.

Furthermore, leadership factor determines the structure, processes, budget and final outcome of the commission. This suggests that the leadership profiles of the initiators of truth commissions are perhaps the most crucial explanatory index of its character and its end result. Therefore, for a truth commission to succeed, it requires a set of conceptual and philosophical guidelines that will enable it to lay a solid foundation for an enduring democracy and effective national reconciliation. Leadership holds the keys for such transformation to take place. 
Conflicts, Truth Commission and Democratic Consolidation in Africa: Addressing human rights issues is central to conflict management and democratic consolidation in any post-conflict context. Democracy on its own part epitomizes a continuous process of promoting equal access to fundamental rights (NzongolaNtalaga, 2000). Human rights issues have therefore been canonized as a cornerstone of post-conflict reconstruction of societies that are just emerging from violent conflicts and repressive regimes. Following the adoption of the Universal Declaration of Human Rights in 1948, human rights have not only been institutionalized in the internal politics of nation states, but have also become a major force to reckon with in international politics. The rights of persons within the community have been advanced through groundbreaking United Nations procedures that have progressively established their universality, indivisibility and their connectivity to development and democratization.

For most post-conflict societies of the world, addressing past injustices and leading victims of war or repressive regimes on the path of reconciliation are perhaps major challenges to democracy and good governance. Most countries of the world emerged from harrowing experiences of armed conflicts, ethnoreligious skirmishes, political turmoil, natural disasters and repressive/autocratic regimes. Recent events around the world indicate that our planet is yet to experience the most treasured assets - peace and development. The intensification of conflicts has resulted in unprecedented humanitarian crises that often gave rise to the phenomenon of failed or collapsed states. In Africa, and indeed recently, the Middle East, the quantum and the ravaging effects of authoritarian rule and armed conflicts are indeed enormous.

Africa is no doubt the most devastated region by internal crises and their attendant catastrophic consequences (Deng, 2000). According to Chapman and Ball (2001), the 20th century predisposes many African nations to collective violence and severe human rights violations. The brutal apartheid regime in South Africa, genocidal wars in Rwanda and Burundi, the ethnic cleansing in the former Somalia, state terrorism in the Darfur region and military dictatorships in Nigeria are just few of such cases. Hardly has a state emerged in Africa without a major civil war or internal conflagration. This pitiable condition Africa finds itself is firmly rooted in colonialism and imperialism (Stark, 1996) and of course the ascendancy of one party/authoritarian rule and apartheid regime (as in the case of South Africa) in the post colonial era. Under one-party regimes, most especially the military, rights of persons were routinely violated. Rapes, assassinations, assaults, sudden disappearances of persons and lootings of both public and private holdings reached climax. Ironically, most of these infractions were state-sponsored.

Oftentimes, state's actors and their cronies were implicated as key perpetrators of such heinous crimes. Lamenting the roles of policy makers in explosive conflict aggravation, Kofi Annan, former Secretary-General of the United Nations identified 'particularistic and exclusionary form of identity politics' as responsible for some of the violations of human rights laws that have precipitated hostile conflicts of unimaginable consequences around the world (Annan, 2003). Such unfortunate and painful experiences often pose serious threats to post-conflict peace building and democratic processes. Post-conflict states have discovered Truth Commissions or National Reconciliation Commissions as veritable instruments of transition from near societal collapse and authoritarian breakdown to a more stable democratic order. When civil wars or intrastate conflicts end, and dictatorships, military junta, or repressive or other oppressive authoritarian regimes are defeated, creating a truth commission is one way for a society and individuals to deal with atrocities of the recent past. Transitional societies need to confront the painful burden of the past in order to achieve a holistic sense of justice for all citizens, to restore civic trust and to reconcile people and communities to prevent future reoccurrence.

There are three unique ways truth commissions can contribute innovatively to democracy. First, truth commission is primarily concerned about past human rights by making its violators accountable and restoring victims to normal life. Strict adherence to human rights norms validates the consolidation of democratic ideals in any transitional polity. Democracy in the words of Nzongola-Ntalaja (2002) is a process for 'expanding the political space and promoting equal access to fundamental human rights for all'. Secondly, truth commissions can set the tone for effective reconciliation to take place for hostile groups or deeply divided societies that are undergoing transition. In other words, for democracy to flourish, the people concerned require a fair dose of reconciliation, since only a truly reconciled society can indeed pursue democracy and good governance zealously. 


\section{Three Case Studies of Truth Commission in Africa}

(a) Sierra Leone Experience: The Sierra Leonean Truth and Reconciliation Commission was formally inaugurated on July 6, 2002 and was a by-product of the Lome Peace Agreement signed by the government of Sierra Leone under President Ahmad Tejan Kabbah and the Revolutionary United Front of Sierra Leone in July 1999. According to Article 26 of the Peace Agreement that established the commission:

A Truth and Reconciliation Commission shall be established to address impunity, break the cycle of violence, provide a forum for both the victims and perpetrators of human rights violations to tell their story, get a clear picture of the past in order to facilitate genuine healing and reconciliation. The commission was made up of seven (7) members, three of whom were foreigners. Its activities were divided into three main phases: a deployment stage, a hearing stage and report writing stage. The commission received well over 6000 statements from members of the public before proceeding to the hearing stage at which many leading figures including Valentine Stressed (former military ruler) and President Tejan Kabbah testified (Evenson, 2004). Section 6(1) of the Act that set up the commission identifies the following as cardinal objectives of the Sierra Leonean Commission:

- To create an impartial historical record of violations and abuses of human rights and international humanitarian law related to the armed conflict in Sierra Leone, from the beginning of the conflict in 1991 to the signing of the Lome Agreement

- To address impunity

- To respond to the needs of victims

- To promote healing and reconciliation

- And to prevent repetition of the violation and abuses suffered

There are other features that made the commission a unique outfit. First, the commission adopted an open and unconditional amnesty stance. That is, the commission reserves the right to grant pardon to all those found guilty of human rights violation unconditionally. This has become a major object of criticism to the commission. For its critics, the offer of unconditional pardon to perpetrators amounted to injustice and could foreclose the prospects of reconciliatory gestures in the beleaguered state. Second, the Sierra Leonean option operated a Special Court concurrently with the truth commission. This Special Court was meant to deal with individuals or organizations suspected to have committed crimes against humanity and war crimes (Fombad, 2004: 202). This also created a mix-up as observed by Charles Fombad that 'the co-existence of the TRC and a Special Court with possible overlapping jurisdiction is one of the unique and possible confusing aspects of the Sierra Leone TRC process (Fombad, 2004).

Thirdly, the TRC Act was enacted into law, with its passage of the bill into law by the Sierra Leone Parliament on 22 February, 2000. This is an important aspect of setting up a truth commission. A commission set up without an enabling law may not be able to stand the test of time. It will not only retain the existence of its own but will also insulate it from the undue influence of the powers that be. The last feature of the Sierra Leonean commission is that it made provisions for reparations to be paid to victims of human rights abuses. Fourthly, the TRC Act also empowered the commission to make recommendations on the operations of War Victims Fund. It envisaged that through this fund, those who were devastated by the war could be assisted through a reparation programme. The category of victims that qualified for reparations was narrowly defined as the amputees, the war-wounded, victims of sexual violence and abuse, and children. Under this category were also the aged and other vulnerable groups whose productive capacity fell below $50 \%$.

(b) South African Truth and Reconciliation Commission; The collapse of apartheid regime in the early nineties finally paved way for the first multi-racial election to take place in South Africa in 1994. Nelson Mandela, perhaps the longest-serving political prisoner in the world, was subsequently sworn-in as the first black President in that country. Based on the pacted affair that characterized the transition, the major parties in the conflict - African National Congress (ANC), the National Party (NP) and the Inkatha Freedom Party (IFP) agreed to set up a Truth and Reconciliation Commission as a way of establishing the accurate record of the country's past'(Hayner, 1996). The Promotion of National Unity and Reconciliation Act that established 
the commission empowered it to investigate series of human rights abuses that were perpetrated during the apartheid years. The Commission was established with the following terms of reference:

- To analyze and describe the causes, nature and extent of gross human rights violations that occurred between March 1, 1960 and May 10, 1994 and identifies individuals and organizations responsible for such violations.

- To make recommendations to the President on how to prevent future occurrence of such violations.

- The restoration of human and civil dignity of victims of gross human rights violations through testimony and recommendations to the President.

- Granting amnesty to those who make full disclosure of relevant facts relating to acts associated with political objective.

The commission was empowered through this Act to subpoena witnesses, offer amnesty in exchange for confessions, and prepare reparations to victims. The TRC was aimed at fostering reconciliation between previous adversaries in the new South Africa. The Truth and Reconciliation Commission (TRC) was set up through a Parliamentary Act to unearth the mysteries surrounding the long years of apartheid rule in South Africa. The TRC had 17 Commissioners, as well as well over 400 staff. It also had 4 giant offices spread across the country and an annual budget running to over USD \$18 million. TRC had testimonies from 23,000 victims and witnesses of which about 2000 appeared in the public hearings.

The South African Truth and Reconciliation Commission were unique in a number of ways. First, it was backed by enabling laws in the sense that the commission was established by a Parliamentary Act, that is, the Promotion of National Unity and Reconciliation Act of 1995. In other words, the commission was constitutionally sanctioned. Another unique aspect of the TRC was the incorporation into its work the Christian religious doctrine or notion of apology and forgiveness. Furthermore, the TRC evolved a three layered committee system, namely: the Amnesty Committee: oversaw the applications for amnesty; the Human Rights Violation Committee: - coordinated the collection of statements from victims and witnesses and the Reparation and Rehabilitation Committee that supervised the reparation programme. Amnesty was granted for only politically motivated crimes. In other words, South African TRC stipulated certain conditions an applicant must meet to qualify for amnesty. The first is a full disclosure of politically motivated crimes (confession for amnesty). The second is the issue of proportionality between the crime committed and the political objective pursued (Freeman \& Hayner, 2003).

Although the TRC in South Africa faced some logistic problems, particularly those that had to do with the payment of reparations to victims, it remains the most ambitious and referenced attempt to reconcile a nation that emerged from the ruins of apartheid in the world.

(c) Human Rights Violation Investigation Commission in Nigeria: Upon his swearing-in on May 29, 1999, President Obasanjo, who himself was a victim of a phantom coup under the former maximum ruler, General Sanni Abacha inaugurated the Human Rights Violations Investigation Commission (a.k.a Oputa Commission) on 14, June, 1999. The Commission, chaired by the renowned jurist, Justice Chukwudifu Oputa (rtd.) was to investigate, among other things, human rights violations of the past regimes from 1966-1999. The fact-finding commission was patterned after the South African Truth and Reconciliation Commission to investigate past human rights violations, the victims, causes of the violations and proffer appropriate recommendations in order to reconcile the aggrieved in the society and possibly prevent such occurrences in the future. It was therefore expected that the commission would unravel the mystery of past human rights abuses in Nigeria, restore people's confidence and trust in the state and put Nigeria and Nigerians on the path of reconciliation. Albert (2007) presents the following as The Oputa Commission's mandate:

- Establish or ascertain the causes, nature and extent of human rights violations or abuses in Nigeria between 1966 to 1999 ;

- Identify the person or persons, authorities, institutions that were responsible for human rights abuses and determine the motives of the violations

- Determine whether such abuses or violations were deliberate state policies or acts of state officials or acts of any political organization, liberation movement or other groups or individuals; and

- Recommend measures which may be taken whether judicial, administrative, legislative or institutional to redress the injustices of the past or prevent a reoccurrence in the future. 
Unlike the two previous commissions discussed in this work, the Oputa Commission was set up under the Tribunal of Enquiry Act, an Executive power conferred on the President to create such a commission. In other words, Oputa Commission was set up through an executive fiat (Albert, 2007). This development had grave implications for the process and outcome of the commission. For instance, the National Assembly challenged the power of the President to set up a commission without recourse to the legislative body. It took a while before the commission started its work. Furthermore, despite the commission submitting its report in July 2002, the government was yet to release a white paper on it. In fact, the commission had to face several court cases from aggrieved individuals who challenged its legality in the law court. Also, as a total departure from the previous commissions, The Oputa Commission did not have the amnesty clause included in its mandate. Perpetrators did not have the opportunity to apply for amnesty for human rights violations committed. In fact, the proceedings at the commission were more or less a replica of court sessions as attorneys and suspects engaged victims in a legal tussle. Interestingly also, the commission's summon of three former heads of states - Generals Mohammadu Buhari, Ibrahim Babangida and Abubakar Abdulsalami - was not heeded and could not be enforced. This put to test the constitutionality of the commission.

Empowering Truth Commissions for Democratic Consolidation: African experiences with truth commissions as chronicled earlier have raised a number of pertinent issues. In retrospect, there seems to be a consensus around the world today that there is a crisis or absence of leadership (Ikenberry, 1996: 387). This leadership question has traversed virtually all facets of human endeavour including family, organizations and politics. Truth commissions are no exception and transformative leadership option provides the necessary support that will make it relevant to the democratic equation of the states that are trying to overcome past traumas. Experience has shown that the relative successes recorded in South Africa and Sierra Leone (at least at the level of producing a well-circulated report) hinged on the ability of their leaders to pursue parliamentary approval for the establishment of their truth commissions. In the case of Nigeria, the Tribunal Enquiry Act on which the President relied to set up the Oputa Commission did not conform to the democratic mood of the new government in 1999. This suggests a lack of transformational leadership which goes beyond 'having the authority to exercise power in order to influence the course of actions an individual can have the power and the authority to lead but he still needs something else to be considered a political leader. If authority is given by rules, norms, institutional settings or contextual and historical determinants, it means it rests on others' agreement or submission (Nunes, 2010).

Further clarification was made by Isaac Albert regarding the fundamental flaws of the Oputa Commission: The establishment of the commission and its terms of reference have been interpreted in diverse (and sometimes, bizarre) ways by Nigerians. This derived from the fact that most Nigerians were not consulted before it was established. This left ample room for speculation, skepticism and it ultimately created a number of problems. This is one of the reasons why the commission has no report to date (Albert, 2007). The essence of Albert's argument is that for truth commissions to be instrumental to consolidating democracy, the process that sets it up must as a matter of necessity be democratic. South African TRC for instance attracted goodwill in terms of logistic support and funding from several local and international agencies. Thus, despite the overwhelming nature of its work, funding was the least of the problems that the TRC faced in South Africa. The South African Truth and reconciliation Commission had visible transformational leadership. According to Tutu (2003):

'There is no handy roadmap to reconciliation. There is no simple prescription for healing the wounds and divisions of a society in the aftermath of sustained violence...each society must discover its own route to reconciliation'

One other important aspect that transformative leadership can impact positively on truth commissions is in the area of reparation. Reparation is crucial to healing and reconciliation. This is an area most truth commissions have defaulted. A visionary and transformational leader recognizes the fact that economic justice has restorative effects on victims of wars and authoritarianism.

\section{Conclusion and Recommendations}

The major post-conflict challenge that Africa faces today is developing appropriate responses to the myriad of destructive conflicts that have held the continent hostage for several decades. These responses are germane to democratic consolidation in nations that are trying to overcome past abuses. Truth commissions offer a 
timely intervention for the democratic agenda of these states. However, the relationship between a truth commission and democratic consolidation is not automatic. Certain intervening variables have to be mobilized to validate this linkage. Transformative leadership holds the key for making truth commissions fulfill this democratic agenda and also helps to transmute African developmental aspirations into concrete action. Transformative leadership will not only seek constitutional means of adopting a truth commission but will also garner both local and international support to ensure the success of the whole post-conflict peacebuilding efforts.

It is thus argued in this paper that transformational leadership will foresee and avoid the danger of shielding away from pursuing legislative support for a truth commission. This is not just for its democratic imperative but as a strategy for mobilizing both local and international support for the success of commission. Transformative leadership option can also assist in adjusting truth commission's efforts to meet local needs. The insertion of the amnesty clause and the adoption of Christian religious doctrine (although often criticized) perhaps epitomized the resources of transformative leadership into the calculus of national reconciliation initiatives in South Africa. Leaders are objects of an immense admiration, due to their ability to change the lives of their followers.

James (2008) argues that the utility of an empowering style of leadership should not be confined to Europe or America, but should touch on core principles of human behavior that are expressed in the African notion of Ubuntu (Ubuntu means I am because we are). Therefore, future research interest can focus on the different leadership characteristics and behaviours in order to determine the psychological mediating mechanisms that impact democratization in Africa.

\section{References}

Albert, I. O. (2007). Nigerian Truth and Reconciliation Commission and the Crises of Interpretation in Albert I.O. (Ed.) Local Approaches to Conflict Transformation in Nigeria. Ibadan: University of Ibadan, CEPACS.

Albert, I. O. (2003). Mainstreaming Positive Leadership in Conflict Transformation in Nigeria. Positive Leadership Monograph Series. CSSR\&D.

Annan, K. (2003). In Jega Attahiru, (ed.) Identity Transformation and Identity Politics under SAP in Nigeria. Uppsala: Nordiska Afrikainstitutet.

Borer, T. A. (2005). Truth Commissions. In C. van den Anker \& R. Smith (Eds.). The Essential Guide to Human Rights. London: Hodder Arnold.

Boyatzis, R. E. \& McKee, A. (2005). Resonant leadership: Renewing yourself and connecting with others through mindfulness, hope, and compassion. Cambridge, MA: Harvard University Press.

Chabal, P. E. (1984). Review of John Cartwright Political Leadership in Africa. Journal of the International African Institute, 54(3), 108-110.

Chapman, A. R. \& Ball, P. (2001). The Truth of Truth Commissions: Comparative Lessons from Haiti, South Africa and Guatemala. Human Rights Quarterly, 23(1), 1-43.

Den Hartog, D. N., House, R. J., Hanges, P. J., Ruiz-Quintanilla, S. A. \& Dorfman, P. W. (1999). Culture specific and crossculturally generalizable implicit leadership theories: Are attributes of charismatic/transformational leadership universally endorsed? Leadership Quarterly, 10(2), 219256.

Deng, F. M. (2000). Anatomy of Conflicts in Africa in Nnoli Okwudiba ed. AAPS Books, Harare.

Denton, M. \& Vloeberghs, D. (2003). Leadership challenges for organizations in the New South Africa. Leadership \& Organisation Development Journal, 24(2), 84-95.

Evenson, E. M. (2004). Truth and Justice in Sierra Leone: Coordination between Commission and Court. Columbia Law Review. 104(3), 730-767.

Fombad, M. C. (2009). Prospects for Peace Building through Truth Commissions in Africa. Addis Ababa: OSSREA. 189-219.

Freeman, M. \& Hayner, B. P. (2003). The Truth Commission of South Africa and Guatemala. Stockholm: IDEA.

Freeman, M. \& Hayner, P. (2006). Truth Commissions and Procedural Fairness (1st Ed.) New York: Cambridge University Press. 
George, B. (2003). Authentic leadership: Rediscovering the secrets to creating lasting value. San Francisco: Jossey-Bass.

Hayner, P. B. (1994). Fifteen Truth Commissions-1974 to 1994: A Comparative Study. Human Rights Quarterly, 16(4), 597-655.

Hayner, P. B. (1996). Commissioning the Truth: A Further Research Questions. Third World Quarterly, 17(1), 19-29.

Ikenberry, J. (1996). The Future of International Leadership. Political Science Quarterly, 111(3), 385-402.

James, R. (2008). Leadership development inside-out in Africa. Nonprofit Management \& Leadership, 8(3), 359-375.

Jensen, S. M. \& Luthans, F. 2006. Entrepreneurs as authentic leaders: impact on employees' attitudes. Leadership \& Organisation Development Journal, 27(8), 646-66.

Kapur, A. C. (1981). Principles of Political Science. New Delhi: S. Chand \& Company.

Liden, R. C., Wayne, S. J., Zhao, H. \& Henderson, D. (2008). Servant leadership: Development of a multidimensional measure and multi-level assessment. The Leadership Quarterly, 19, 161-177.

Nel, P. S., Werner, A., Haasbroek, G. D., Poisat, P., Sono, T. \& Schultz, H. B. (2008). Human Resources Management $7^{\text {th }}$ Ed. Cape Town: Oxford.

Nielsen, K., Yarker, J., Randall, R. \& Munir, F. (2009). The mediating effects of team and self-efficacy on the relationship between transformational leadership, and job satisfaction and psychological well-being in health-care professionals: A cross-sectional questionnaire survey. International Journal of Nursing Studies, 46, 1236-1244.

Nunes, F. J. C. T. (2010). The analysis of Political Will and its role in Leadership: a study of Portuguese Mayors. Unpublished Postgraduate dissertation. Universidade de Aveiro.

Nzongola-Ntalaga, G. (2000). Democracy and Development in Africa: A Tribute` in Africa: A Tribute to Claude Ake. Claude Ake Memorial Lecture, 2000. African Centre for Democratic Governance, Abuja. Series No. 4.

Oputa, C. (2006). Achebe Foundation Interviews: Justice Chuwkudifu Oputa (Rtd) in conversation with Nduka Otiono and Chris B. Ogbogbo. 10 March 2006.

Quinn, J. \& Freeman, M. (2003). Lessons Learned: Practical Lessons Gleaned From the Truth Commissions of Guatemala and South Africa. Human Rights Quarterly, 25(4), 1117-1149.

Robbins, S. P., Judge, T. A., Odendaal, A. \& Roodt, G. (2009). Organisational Behaviour. Global and Southern African Perspectives $2^{\text {nd }}$ Ed. Cape Town: Pearson.

Rosembloom, D. (1998). Public Administration; Understanding Management, Politics and Law in the Public Sector. New York: McGraw-Hill.

Rousseau, J. J. (2008). A discourse upon the origin and the foundation of the inequality among mankind. New York: Cosimo.

Sashkin, M \& Rosenbach, W. E. (1993). A new leadership paradigm, in W.E. Rosenbach \& R. L. Taylor (Eds.). Contemporary Issues in Leadership. Boulder, San Francisco and Oxford: Westview Press.

Smit, P. J., Cronje, G. J. D., Brevis, T. \& Vrba, M. J. (2007). Management Principles. A contemporary Edition for Africa. $4^{\text {th }}$ ed. Cape Town: Juta.

Stark, F. M. (1996). Theories of Contemporary State Formation in Africa: A Reassessment. The Journal of African Studies, 24(2), 335-347.

Teitel, R. G. (2003). Human Rights in Transition: Transitional Justice Genealogy. Harvard Human Rights Journal, 16(69): 69-94.

Tichy, N. M. \& Devanna, M. A. (1990). The transformational leader (2nd Ed). New York: Wiley.

Tutu, D. (2003). The International IDEA Handbook Series: Forward. International Institute for Democracy and Electoral Assistance.

Van Zyl, E. (2009). Leadership in the African context. Cape Town: Juta.

Vora, V. J. A \& Vora, E. (2004). Effectiveness of South Africa's Truth and Reconciliation: Perceptions of Xhosa, Afrikaner and English South Africans. Journal of Black Studies, 34(3), 301-322.

Zalaquett, J. (1997). Truth Commissions: A Comparative Assessment. An Interdisciplinary Discussion held at Harvard Law School, May 1996. Harvard: Harvard Law School Human Rights Program. 